\title{
Organoleptic evaluation of sweet cherry varieties
}

\author{
Takácsné Hájos, M. ${ }^{1}$, Nyéki, J. ${ }^{1}$, Veres, E. ${ }^{1}$, Fieszl, Cs. ${ }^{1}$ \& Szabó, Z. ${ }^{1}$ \\ ${ }^{1}$ University of Debrecen Centre for Agricultural and Applied Economic Sciences, \\ H-4032 Debrecen, Böszörményi str. 138., Hungary
}

\begin{abstract}
Summary: The extraordinary abundance of precipitation in 2010 (somewhere around $1000 \mathrm{~mm}$ ) influenced highly the development of taste and flavour in cherry fruits. As stated, only a few varieties out of 27 were acceptable as for commercial quality. Under the given climatic conditions, actually 'Bigarreau Burlat' earned 965.11 points and proved to be the best in the early ripening group. In the mid season group, three varieties earned more than 1000 points ('Giant Red', 'Carmen' and 'Vera' grown at Nagykutas and Pallag), whereas in the late ripening group 'Germesdorfi' sent from Csenger (1084), 'Linda' (1070.07) and 'Lapins' (1052) received recognition.

Correlation has been tested on the basis of 27 varieties between the individual properties. We sated that the most important attributes, which influenced the general impression of decision makers are the following: form and size of the fruit ( $\mathrm{r}=0.835$ and 0.797$)$, furthermore juiciness $(\mathrm{r}=0.776)$, taste $(\mathrm{r}=0.876)$ and sweetness $(0.875)$. Crispness was considered to be typical to cherry ( $\mathrm{r}=0.743)$. Relation between acidity and sweetness was also essential to determine the acceptance of the cherry character.
\end{abstract}

Key words: sweet cherry varieties, organoleptic judgement, parameters of quality, numerical rating, soluble solids (Brix\%), acidity $(\%)$

\section{Introduction}

Consumption of fresh sweet cherries tended to decrease in Hungary, recently. It is desirable to find varieties of appropriate quality for fresh consumption, at the same time to be suitable for some kind of processing too (Soltész, 1997). Heritable characters are decisive, as large, crispy fruits are most esteemed, so they are recommended first of all for intensive commercial production (Szabó et al., 1998). It is well known that the majority of varieties are self incompatible, therefore the association the suitable varieties is obligatory (Nyéki, et al., 2004).

A sweet cherry for fresh consumption should be large, well-shaped, crispy and tasty.

During the last years, the preferred size increased from 6-8 g to 9-12 g. (Apostol, 1999; Waterman, 2005). The preference of large fruit size was justified by the panel meetings and sensory judgements (Turner et al., 2008).

The appearance of the fruit exerts the first impression on the consumer when offered on the market. The produce should be clean without wounds, cracking and seem to be bright. The evenness in size, colour and form, deep or bright red makes. For that reason, the light coloured varieties are less desirable in spite of their perfect taste (Kappel et al., 1996).

The consistency of fruit flesh and crispiness are the next requirements (Esti et al., 2002). Though it is easy to measure physical properties, all the same, sensory judgments are more decisive. Sweet taste and crispiness are often opposed because sweetness is increasing with maturity but crispness decreases (Bernalte et al., 1999). Late ripening varieties are usually crispier than early ones as genetically determined
(Christensen, 1995). The desired crispiness means 0.25 $\mathrm{kg} / \mathrm{cm}^{2}$ firmness (Kalyoncu et al., 2009).

The flavour substances play an important role in building up a desirable taste. Altogether sweetness, acidity, bitterness (iso-coumarine) and mineral salts are the main components being present according to a delicate balance. Sugars and acids are the most decisive. The flavouring attributes are shown in Table 1. (Bernalte, et al., 1999).

Table 1 The relationship of components on flavour

\begin{tabular}{|l|l|}
\hline \multicolumn{1}{|c|}{ Flavour attribute } & \multicolumn{1}{c|}{ Constituents } \\
\hline Sweetness & Sugars \\
\hline Sourness & Acids \\
\hline Astringency & Phenolics, tannins \\
\hline Bitterness & Isocumarins \\
\hline Aroma & Odour-active volatiles \\
\hline Off-flavour & Acetaldehyde, ethanol, ethyl \\
\hline Off-odours & Sulphurous compounds \\
\hline
\end{tabular}

Varieties contain different quantities of sugars and acids. A substantial part sugars are fructose and glucose associated with some sacharose. Important acids are the ascorbic acid, siccinic and fumaric acid (Girard \& Kopp, 1998).

The right proportion of sugars/acids is important requirement of a good taste as shown in Table 2 (Revell, 2008).

Earlier results indicated that sweetness is dependent on the ratio of fructose $\left(\mathrm{Brix}^{\circ}\right) /$ acids (Guyer et al., 1993). Other authors stick to the idea that sensory judgements are preferable to tests performed in laboratory, which may 
Table 2 The relationship of sugar/acid ratio versus flavour

\begin{tabular}{|c|c|c|}
\hline \multirow{2}{*}{ Acids } & \multicolumn{2}{|c|}{ Sugar } \\
\cline { 2 - 3 } & High & Low \\
\hline Moderate to high & Best flavour combination & Sour, tart \\
\hline Low & Sweet & Insipid, tasteless \\
\hline
\end{tabular}

contradict each other (Hampson et al., 2000). This opinion is supported by the fact that the taste perceived cannot be ascribed to the effect of a few substances identified by chemical tests as the sugars and acids. As most important components of the cherry flavour are less explored (hexanol, E-2-hexanol), let alone how they interact with the former mentioned sugars and acids (Nobles, 1996).

\section{Material and method}

In 2010, 27 sweet cherry varieties have been examined (Table 3) by sensorial tests at the Centre of the Debrecen University, Institute for Horticulture, Research and Development. Samples belonged to 5 different groups of ripening date (2010. June 7.; 15.; 23.; 29.; July 7). The number of members of the panel varied occasionally between 15 and 18. The test applied the preparation and storing of samples was identical with the former described one (Takácsné Hájos et al., 2011). Samples are marked by codes (three letter numbers) placed on uniform dishes (Picture 1) and acclimatised for a favourable room temperature.

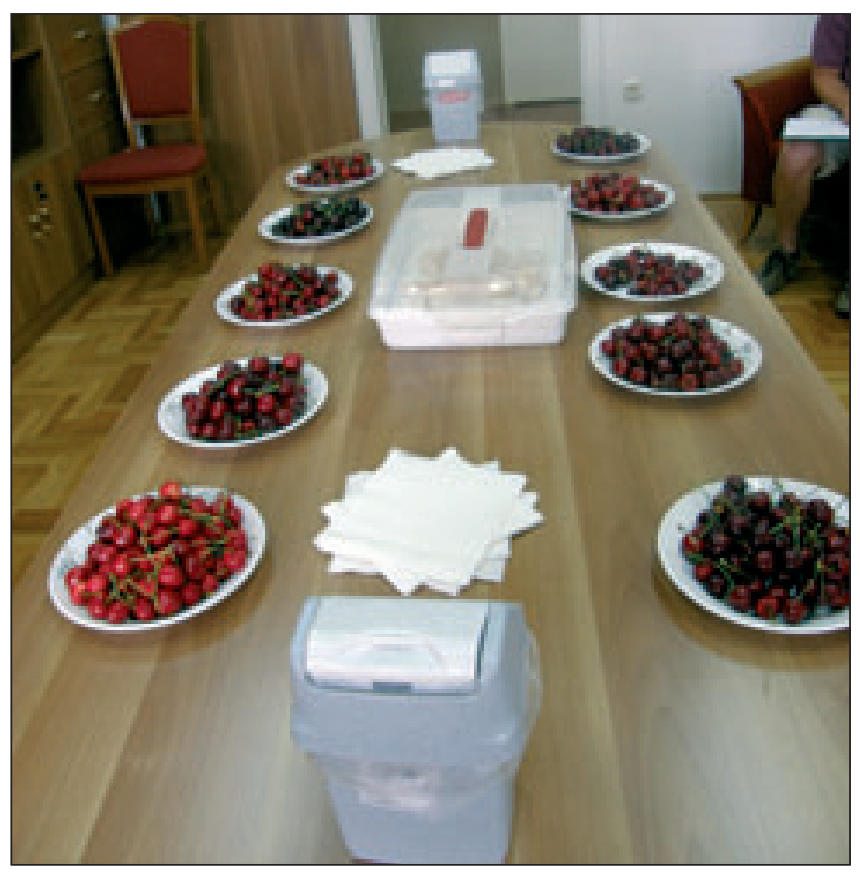

Picture 1 - Presentation of cherry samples

Moments of the sensorial tests have been elaborated as shown in table 4, with the purpose to emphasise those traits, which may become decisive in the choice of sweet cherries for fresh consumption by the consumers. On the form we noted the code, sex, age of the judge and aided the judging by a table of questions, which have to be answered showing the scale of points $(1-100)$ to be given to the individual properties of the samples.

Objective measurements aided the judgement, as the larger width of fruits $(\mathrm{mm})$, the water soluble solids $\left(\mathrm{Brix}^{\circ}\right)$ and acidity (\%) were observed by using a digital refractometer (Atago, PAL-1, Japan). 30 fruits are measured for each sample. The major components of soluble solids being the sugars, sweetness could be expressed largely by the Brix ${ }^{\circ}$.

Results of sensorial judgements and measurements are processed for means and variability, expressed in histograms and profile diagrams. Ripening time groups are processed separately and the scales on the profile diagram started with 50 in order to emphasise the differences among the samples.

Correlation has been calculated between the property means.

Table 3. Sweet cherry varieties selected for the sensorial tests

\begin{tabular}{|c|c|c|c|c|c|}
\hline No & $\begin{array}{c}\text { Variety / maturity } \\
\text { group }\end{array}$ & Origin of samples & Early & $\begin{array}{c}\text { Mid } \\
\text { season }\end{array}$ & Late \\
\hline 1. & Bigarreau Burlat & Pallag & $\mathbf{x}$ & & \\
\hline 2. & Early Star & Pallag & $\mathbf{x}$ & & \\
\hline 3. & Sweet Early & Nagykutas & $\mathbf{x}$ & & \\
\hline 4. & Sándor & Pallag & $\mathbf{x}$ & & \\
\hline 5. & Petrus & Pallag & $\mathbf{x}$ & & \\
\hline 6. & Szomolyai fekete & Pallag & & $\mathbf{x}$ & \\
\hline 7. & Giant Red & Nagykutas & & $\mathbf{x}$ & \\
\hline 8. & Blaze Star & Pallag & & $\mathbf{x}$ & \\
\hline 9. & Paulus & Pallag & & $\mathbf{x}$ & \\
\hline 10. & Aida & Nagykutas & & $\mathbf{x}$ & \\
\hline 11. & Firm Red & Nagykutas & & $\mathbf{x}$ & \\
\hline 12. & Vera $P^{*}$ & Pallag & & $\mathbf{x}$ & \\
\hline 13. & Carmen & Nagykutas & & $\mathbf{x}$ & \\
\hline 14. & Canada Giant & Nagykutas & & $\mathbf{x}$ & \\
\hline 15. & Vera NK* & Nagykutas & & $\mathbf{x}$ & \\
\hline 16. & Cristallina & Nagykutas & & $\mathbf{x}$ & \\
\hline 17. & Santina & Nagykutas & & $\mathbf{x}$ & \\
\hline 18. & Germesdorfi 3 & Nagykutas & & & $\mathbf{x}$ \\
\hline 19. & Van & Pallag & & & $\mathbf{x}$ \\
\hline 20. & Axel & Nagykutas & & & $\mathbf{x}$ \\
\hline 21. & Linda & Nagykutas & & & $\mathbf{x}$ \\
\hline 22. & Katalin & Siófok & & & $\mathbf{x}$ \\
\hline 23. & Germesdorfi Cs* & Csenger & & & $\mathbf{x}$ \\
\hline 24. & Sweet Heart & Nagykutas & & & $\mathbf{x}$ \\
\hline 25. & Regina & Nagykutas & & & $\mathbf{x}$ \\
\hline 26. & Lapins & Pallag & & & $\mathbf{x}$ \\
\hline 27. & Skeena & Nagykutas & & & $\mathbf{x}$ \\
\hline
\end{tabular}

Origin of the fruit:

*P - Pallag

*NK - Nagykutas

*Cs - Csenger 
Table 4. Criteria in deciding fruit quality of the sweet cherry samples

\begin{tabular}{|c|c|c|}
\hline Property & Extreme parameters of the scale & points \\
\hline Form of the fruit & irregular, ............regular, typical & $1 \ldots \ldots 100$ \\
\hline Skin colour, aspect & pale..............intense red, bright & $1 \ldots \ldots 100$ \\
\hline Measure of fruit & small............................ & $1 \ldots \ldots 100$ \\
\hline Flavour & not notable..$\ldots \ldots \ldots \ldots \ldots$ intense & $1 \ldots \ldots 100$ \\
\hline Skin thickness & too thick .......................optimal & $1 \ldots \ldots 100$ \\
\hline $\begin{array}{l}\text { Flesh firmness, } \\
\text { crispiness }\end{array}$ & soft,$\ldots \ldots \ldots \ldots \ldots \ldots \ldots$ firm (crispy) & $1 \ldots \ldots 100$ \\
\hline Juiciness & dry . .................. optimal, juicy & $1 \ldots \ldots 100$ \\
\hline Cherry type savour & slight $\ldots \ldots \ldots \ldots \ldots \ldots \ldots \ldots$. . . . . . . & $1 \ldots \ldots 100$ \\
\hline Sweetness & weak or exaggerated........optimal & $1 \ldots \ldots 100$ \\
\hline Acidity & weak or too sour..............optimal & $1 \ldots \ldots 100$ \\
\hline Disturbing off savour & intense .................. lacking & $1 \ldots \ldots 100$ \\
\hline General impression & not liked................much liked & $1 \ldots \ldots 100$ \\
\hline
\end{tabular}

\section{Results and discussion}

The results of the sensorial tests as well as the results of measurements are presented in Table 5 according to the singular properties. Maximal number of points was 1200, as each property could attain 100 points.

In the early ripening group (5 varieties) Bigarrau Burlat earned the maximum judgement (965.11) and Petrus proved to be the less liked with 801.22 points.

Fruit size was one of the most decisive components of quality, the winner's fruit size was $25.87 \mathrm{~mm}$, which was acceptable in the early ripening group. The general appearance of fruits counterbalanced the relatively low sugar content (9.93\%). Early Star had values of size, sugar- and acid contents (24.48 mm; $10.97 \%$ and 1.27\%) slightly different from that of the winner variety, moreover, better inner quality than of Bigarrau Burlat's. In spite of that, the panel found less favourable values in savour and flavour (Figure 1-4). Petrus is a good example, with $13.57 \%$ sugar and $1.53 \%$ acids being the best, all the same, the sensory judgement assigned the last position for the variety. It is a convincing proof that measurements cannot substitute sensorial judgements.

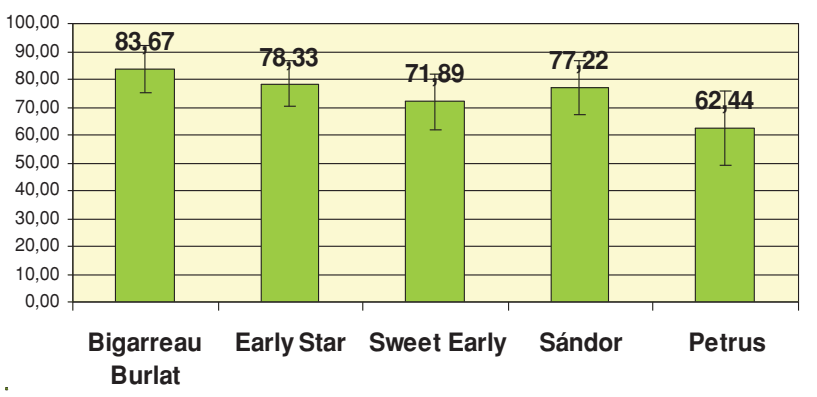

Figure 1. Evaluation of early ripening sweet cherry varieties according to the general impression

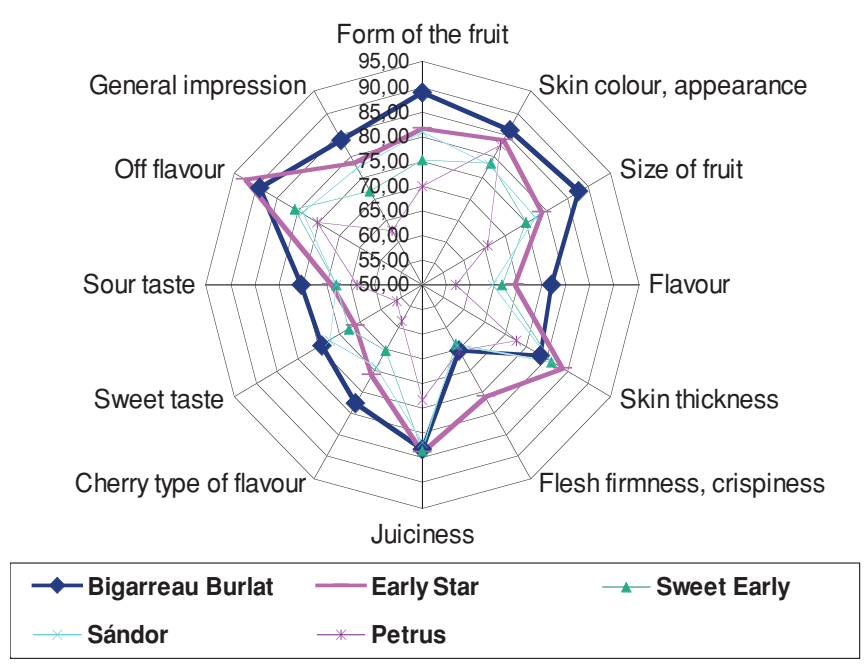

Figure 2. Profile diagram of the evaluation of early ripening sweet cherry varieties according to sensorial judgement

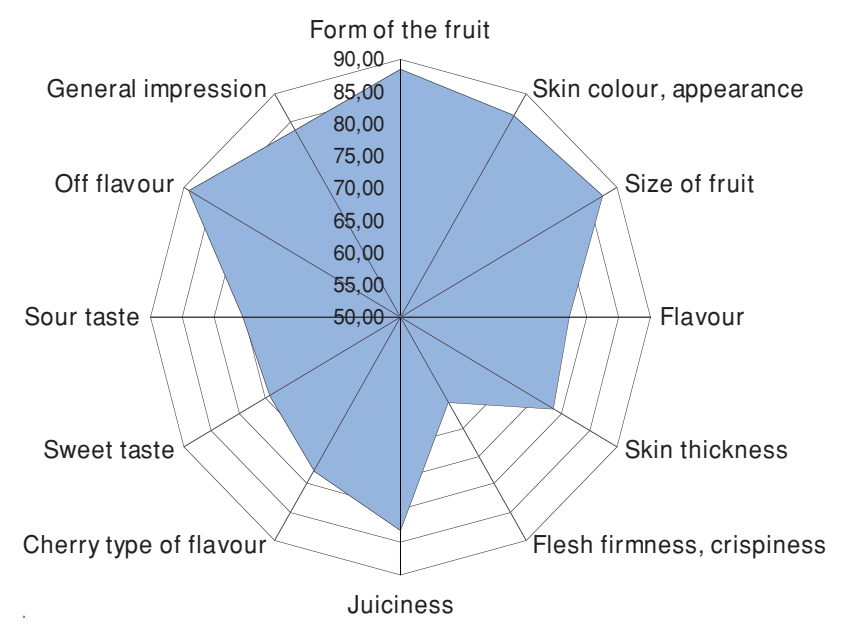

Figure 3. Profile diagram of the sensorial judgement of the variety Bigarreau Burlat

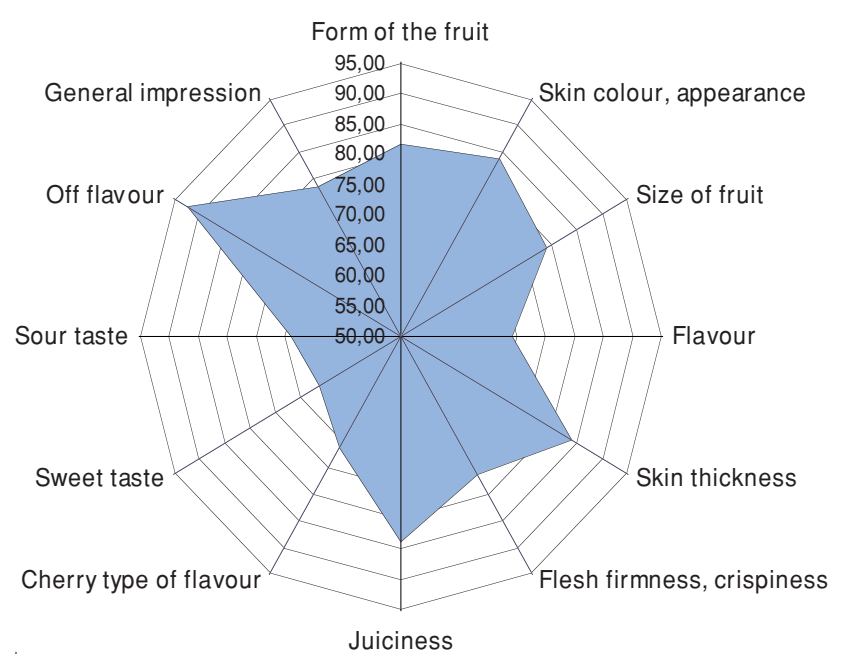

Figure 4. Profile diagram of the sensorial judgement of the variety Early Star 
Table 5. Sensorial judgements of sweet cherry fruits of different varieties according to singular properties. Means and SD values presented

\begin{tabular}{|c|c|c|c|c|c|c|}
\hline Maturity groups & Property/Variety & $\begin{array}{l}\text { Sum of Points } \\
\text { earned } *\end{array}$ & $\begin{array}{l}\text { Largest width of } \\
\text { fruits }(\mathbf{m m})\end{array}$ & $\begin{array}{l}\text { Content of water } \\
\text { soluble substances } \\
(\text { Brix\%) }\end{array}$ & $\begin{array}{c}\text { Content of acids } \\
(\%)\end{array}$ & $\begin{array}{l}\text { Ratio of w.s.subs } \\
\text { versus acids }\end{array}$ \\
\hline \multirow{5}{*}{$\stackrel{2}{\bar{E}}$} & Bigarreau Burlat & 965.11 & $25.87 \pm 1.50$ & $9.93 \pm 0.06$ & $1.50 \pm 0.30$ & 6.62 \\
\hline & Early Star & 933.67 & $24.48 \pm 1.35$ & $10.97 \pm 0.51$ & $1.27 \pm 0.06$ & 8.66 \\
\hline & Sweet Early & 876.22 & $24.43 \pm 1.31$ & $11.5 \pm 0.31$ & $1.15 \pm 0.10$ & 10.00 \\
\hline & Sándor & 892.56 & $25.35 \pm 1.41$ & $11.03 \pm 0.06$ & $0.90 \pm 0.12$ & 12.26 \\
\hline & Petrus & 801.22 & $22.32 \pm 1.04$ & $13.57 \pm 0.06$ & $1.53 \pm 0.12$ & 8.85 \\
\hline \multirow{12}{*}{ 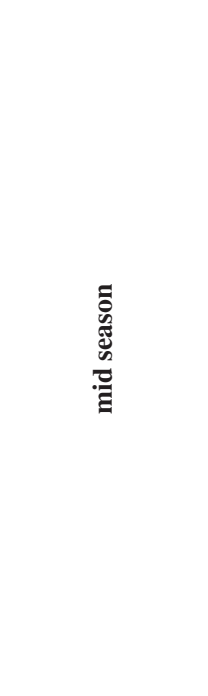 } & Szomolyai fekete & 907.89 & $21.40 \pm 1.27$ & $14.47 \pm 0.06$ & $2.17 \pm 0.06$ & 6.68 \\
\hline & Giant Red & 1027.78 & $27.92 \pm 2.20$ & $17.13 \pm 0.32$ & $3.27 \pm 0.25$ & 5.24 \\
\hline & Blaze Star & 977.67 & $24.32 \pm 0.89$ & $18.50 \pm 0.20$ & $1.70 \pm 0.10$ & 10.88 \\
\hline & Paulus & 914.06 & $23.79 \pm 1.28$ & $13.77 \pm 0.15$ & $1.77 \pm 0.06$ & 7.79 \\
\hline & Aida & 871.00 & $24.49 \pm 1.61$ & $13.93 \pm 0.67$ & $2.90 \pm 0.72$ & 4.80 \\
\hline & Firm Red & 988.28 & $28.06 \pm 1.13$ & $17.00 \pm 0.10$ & $3.83 \pm 0.31$ & 4.43 \\
\hline & Vera $\mathbf{P}$ & 1016.00 & $25.01 \pm 1.54$ & $13.90 \pm 0.12$ & $1.40 \pm 0.10$ & 9.93 \\
\hline & Carmen & 1026.67 & $26.14 \pm 1.56$ & $12.70 \pm 0.12$ & $2.80 \pm 0.41$ & 4.54 \\
\hline & Canada Giant & 971.46 & $26.21 \pm 1.27$ & $13.27 \pm 0.47$ & $4.10 \pm 0.10$ & 3.24 \\
\hline & Vera NK & 1022.23 & $27.42 \pm 0.73$ & $12.52 \pm 1.61$ & $2.67 \pm 0.40$ & 4.70 \\
\hline & Cristallina & 931.92 & $25.27 \pm 1.13$ & $17.90 \pm 0.26$ & $2.50 \pm 0.40$ & 7.16 \\
\hline & Santina & 918.15 & $25.21 \pm 0.93$ & $14.90 \pm 0.53$ & $1.80 \pm 0.46$ & 8.28 \\
\hline \multirow{10}{*}{ 奇 } & Germesdorfi 3 & 932.77 & $26.25 \pm 1.06$ & $13.47 \pm 0.55$ & $1.53 \pm 0.25$ & 8.78 \\
\hline & Van & 963.50 & $24.08 \pm 1.16$ & $17.40 \pm 0.34$ & $1.73 \pm 0.13$ & 10.09 \\
\hline & Axel & 998.80 & $22.96 \pm 1.10$ & $14.87 \pm 0.12$ & $1.57 \pm 0.15$ & 9.49 \\
\hline & Linda & 1070.07 & $25.70 \pm 1.13$ & $17.87 \pm 1.27$ & $3.13 \pm 0.31$ & 5.70 \\
\hline & Katalin & 973.73 & $27.03 \pm 1.62$ & $18.60 \pm 0.46$ & $2.10 \pm 0.17$ & 8.86 \\
\hline & Germesdorfi CS & 1084.00 & $24.72 \pm 1.17$ & $13.40 \pm 0.26$ & $1.83 \pm 0.06$ & 7.32 \\
\hline & Sweet Heart & 929.69 & $23.41 \pm 0.80$ & $15.33 \pm 1.27$ & $2.17 \pm 0.32$ & 7.08 \\
\hline & Regina & 1028.08 & $27.82 \pm 1.15$ & $17.80 \pm 0.85$ & $1.83 \pm 0.25$ & 9.71 \\
\hline & Lapins & 1052.92 & $25.41 \pm 1.35$ & $16.60 \pm 0.44$ & $2.07 \pm 0.15$ & 8.03 \\
\hline & Skeena & 999.23 & $26.30 \pm 0.88$ & $16.25 \pm 0.35$ & $1.95 \pm 0.38$ & 8.33 \\
\hline
\end{tabular}

* maximum of points 1200 , it is the product of 12 properties with maximum 100 points each
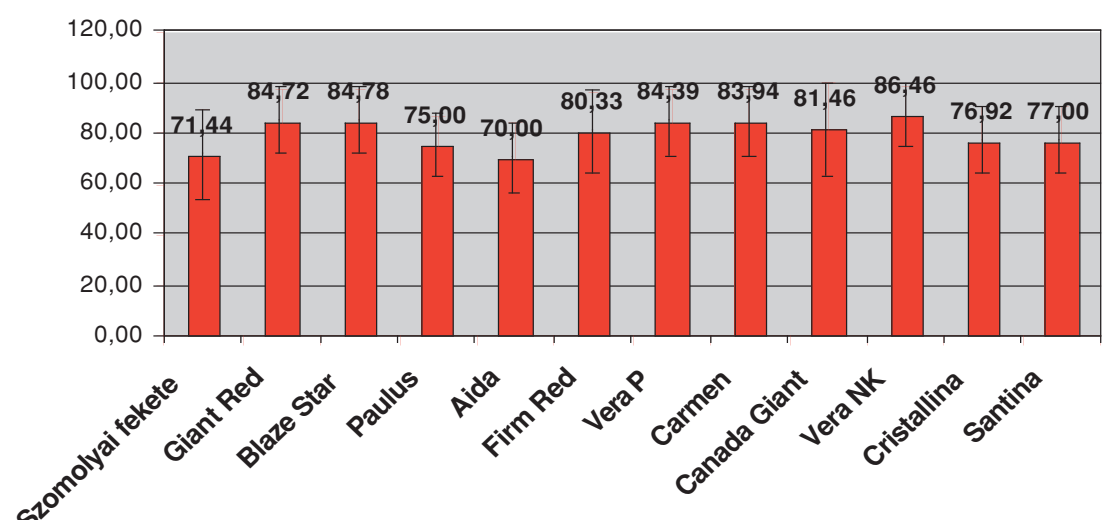

Figure 5. Evaluation of mid season ripening sweet cherry varieties according to the general impression

In the mid season maturity group 12 varieties have been examined. Most of the points have been given to Giant Red (1027.78) and the lager width was $27.92 \mathrm{~mm}$. For Carmen (1026.67 and $26.14 \mathrm{~mm}$ ) and for Vera $N K$ Nagykutasról (1022.23 and $27.42 \mathrm{~mm}$ ) were the correspondent values. Those varieties were rather balanced in the sensorial tests. (Figure 5-9), as expressed in the profile diagrams.

In the late ripening group of ten varieties, we ranked Germesdorfi Cs - 


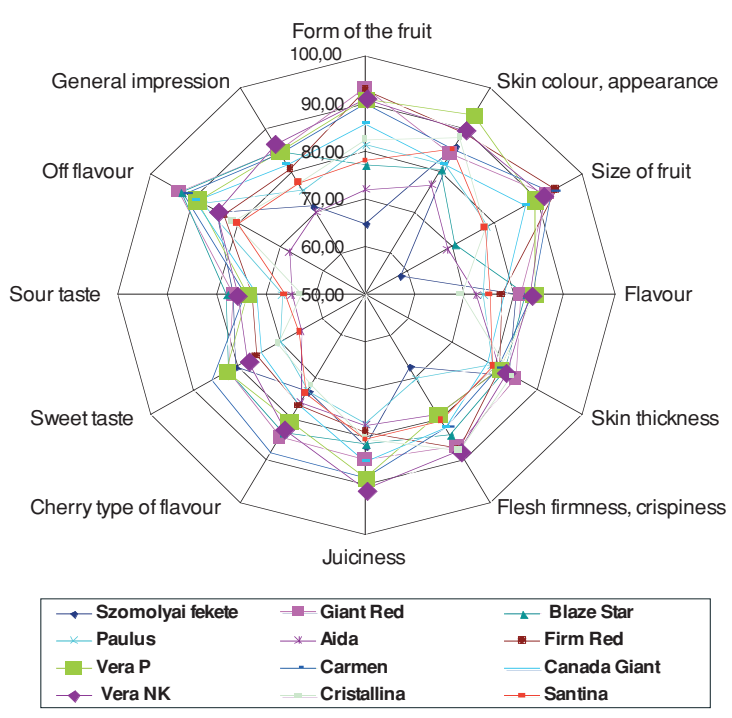

Figure 6. Profile diagram of the evaluation of mid season ripening sweet cherry varieties according to sensorial judgement

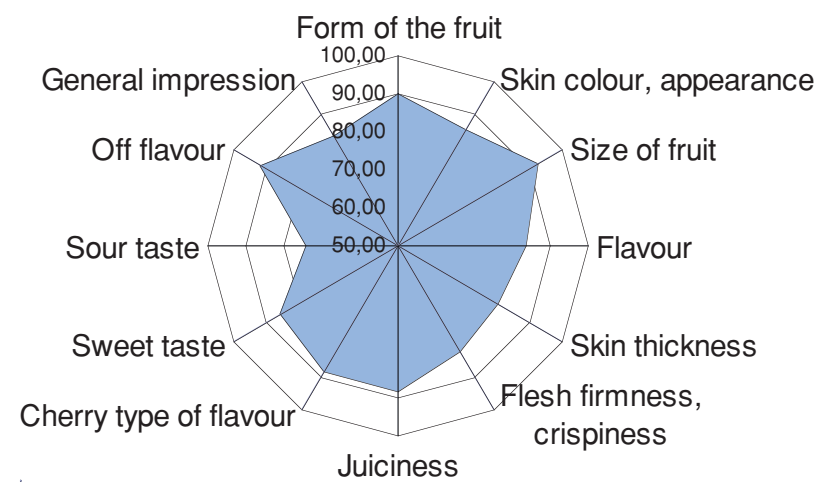

Figure 8. Profile diagram of the sensorial judgement of the variety Carmen

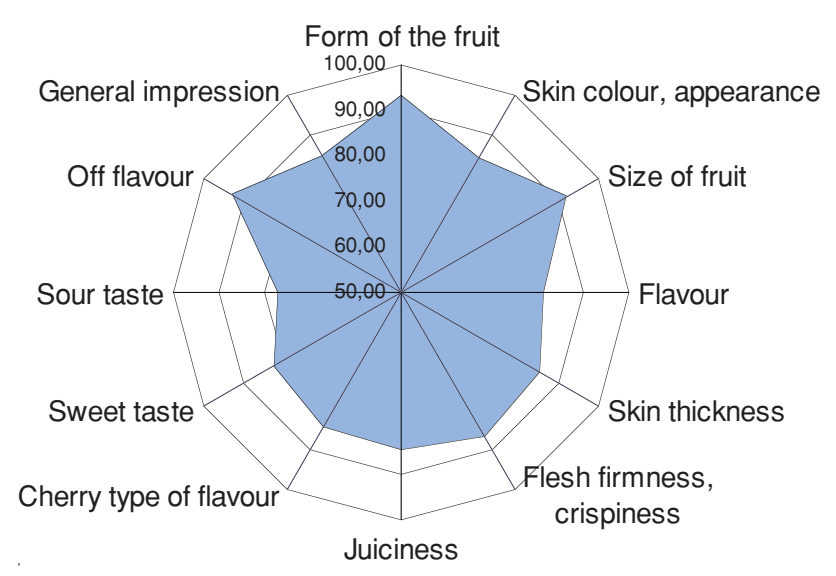

Figure 7. Profile diagram of the sensorial judgement of the variety Giant Red

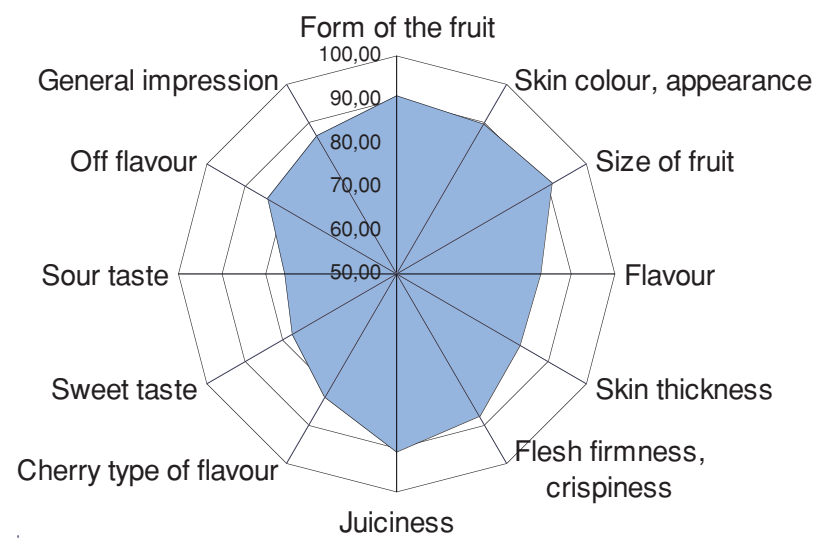

Figure 9. Profile diagram of the sensorial judgement of the variety Vera (NK)

(Csengőd) with 1084.0 points, next Linda (1070.07) and Lapins (1052.92) as nearly so well. It is visible that the panel's decision was based on the aesthetic appearance of the fruits (Figure 10-14). The popularity of the variety is also proved by the saturated circular diagram and the by the points given to general impression.

We may state that the judgement of quality for fresh consumption is required before plantations of larger areas with selected varieties were decided. The target should be to prefer varieties, which are resistant to excessive weather conditions and

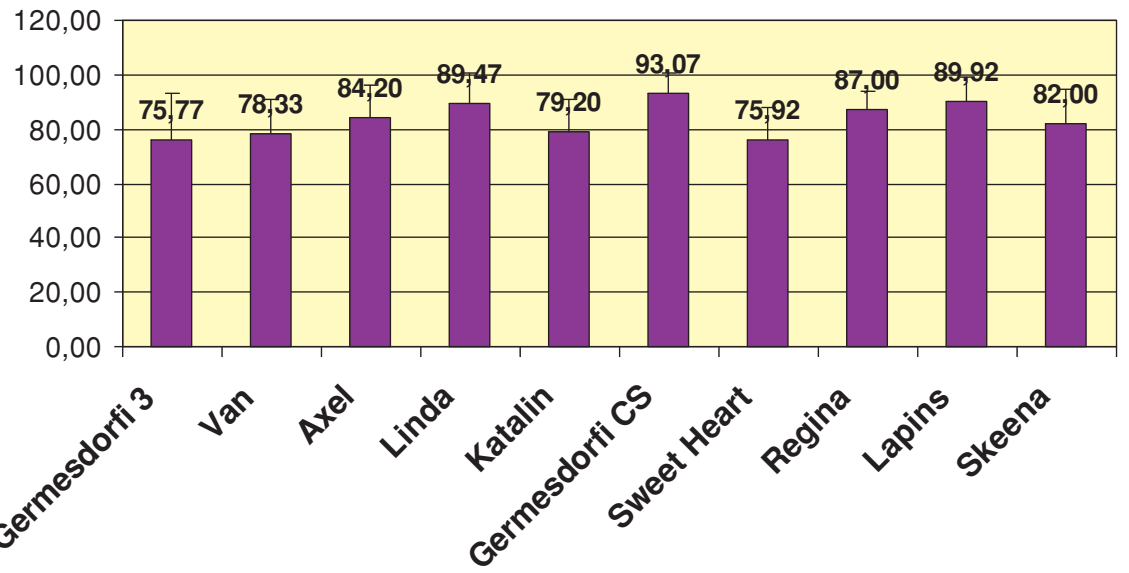

Figure 10. Evaluation of late ripening sweet cherry varieties according to the general impression

keep their quality under adverse moisture and air humidity being competitive on the international market.

Analysis of correlations between the properties examined of 27 sweet cherry varieties produced the results presented in matrix of correlations of Table 6 .

It could be stated that the general impression was highly correlated with those of the form $(r=0.835)$, size $(r=$

0.797) and juiciness $(r=0.776)$, but the role of sherry savour, sweetness and acidity were also decisive $(r=0.873$; $r=0.875 ; r=0.747)$ in contributing to the general impression.

No tight correlations turned out with soluble solids and acids measured versus tastes of sweetness and sourness. Obviously, those properties are more complicated than being 


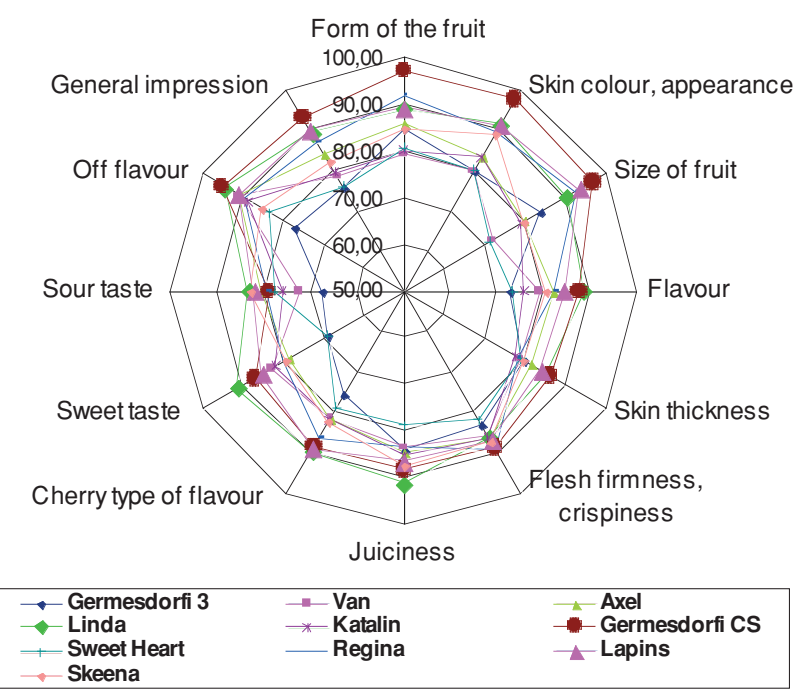

Figure 11. Profile diagram of the evaluation of late ripening sweet cherry varieties according to sensorial judgement

determined by technical instruments in the laboratory. Those results are supported by Hampson et al (2000), stating the same in working with apples.

The sourness of the cherry and the character with sourness and sweetness was tightly correlated $(r=0.798$ and

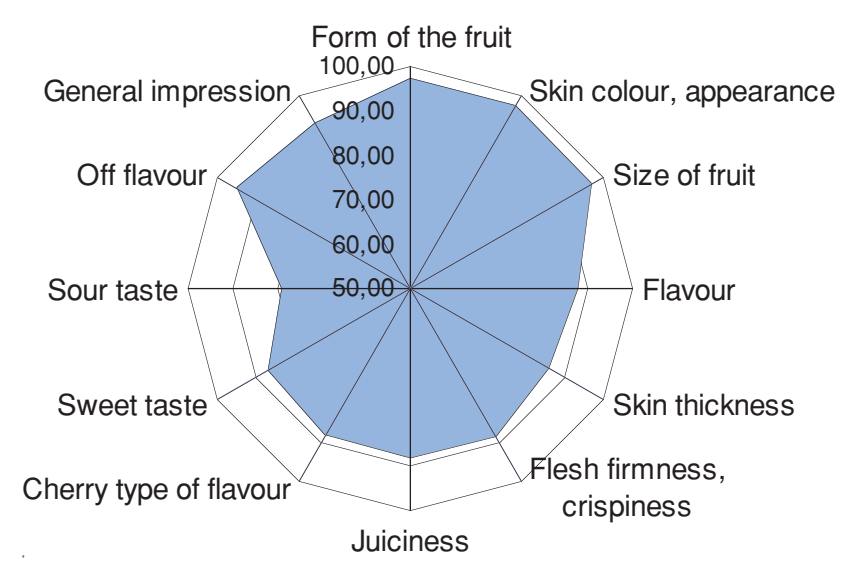

Figure 12. Profile diagram of the sensorial judgement of the variety Germersdorfi (Cs)

$r=0.803$ ). This indicates the chemical components of the savour determine together the typical cherry taste. The sweet taste accentuated by the freshness due to the acids is esteemed by the consumer. The conclusion corresponds with Revell's (2008) paper, which concluded that the best savour depends on the harmony between the high sugar content combined with mediocre or high acid content.

Table 6. A matrix of correlations between the parameters of sensorial judgment of properties rated in sweet cherry fruits $(\mathrm{n}=27)$

\begin{tabular}{|c|c|c|c|c|c|c|c|c|c|c|c|c|c|}
\hline & 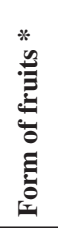 & 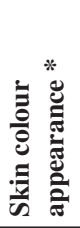 & 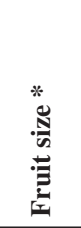 & 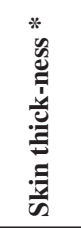 & 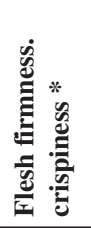 & 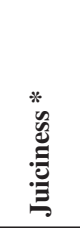 & 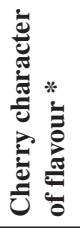 & 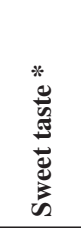 & 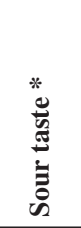 & 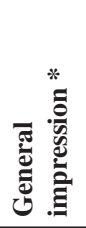 & 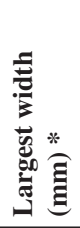 & 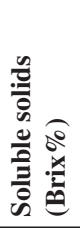 & 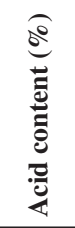 \\
\hline Form of fruits & & 0.642 & 0.962 & 0.337 & 0.618 & 0.618 & 0.664 & 0.544 & 0.475 & 0.835 & 0.699 & 0.079 & 0.192 \\
\hline $\begin{array}{l}\text { Skin colour } \\
\text { appearance }\end{array}$ & & & 0.634 & 0.409 & 0.449 & 0.547 & 0.523 & 0.552 & 0.511 & 0.670 & 0.282 & 0.191 & 0.047 \\
\hline Fruit size & & & & 0.327 & 0.520 & 0.628 & 0.623 & 0.512 & 0.397 & 0.797 & 0.750 & 0.022 & 0.258 \\
\hline Skin thickness & & & & & 0.326 & 0.488 & 0.447 & 0.502 & 0.318 & 0.536 & 0.093 & 0.100 & 0.092 \\
\hline $\begin{array}{l}\text { Flesh firmness. } \\
\text { crispiness }\end{array}$ & & & & & & 0.455 & 0.743 & 0.534 & 0.498 & 0.636 & 0.511 & 0.673 & 0.395 \\
\hline Juiciness & & & & & & & 0.709 & 0.762 & 0.633 & 0.776 & 0.428 & 0.015 & 0.061 \\
\hline $\begin{array}{l}\text { Cherry character } \\
\text { of flavour }\end{array}$ & & & & & & & & 0.873 & 0.798 & 0.873 & 0.436 & 0.440 & 0.254 \\
\hline Sweet taste & & & & & & & & & 0.803 & 0.875 & 0.297 & 0.419 & 0.171 \\
\hline Sour taste & & & & & & & & & & 0.747 & 0.202 & 0.375 & 0.110 \\
\hline $\begin{array}{l}\text { General } \\
\text { impression }\end{array}$ & & & & & & & & & & & 0.506 & 0.234 & 0.100 \\
\hline $\begin{array}{l}\text { Largest width } \\
(\mathrm{mm})\end{array}$ & & & & & & & & & & & & 0.213 & 0.436 \\
\hline $\begin{array}{l}\text { Soluble solids } \\
\text { (Brix\%) }\end{array}$ & & & & & & & & & & & & & 0.347 \\
\hline Acid content (\%) & & & & & & & & & & & & & \\
\hline
\end{tabular}

* signalises that the property was judged by sensorial means 


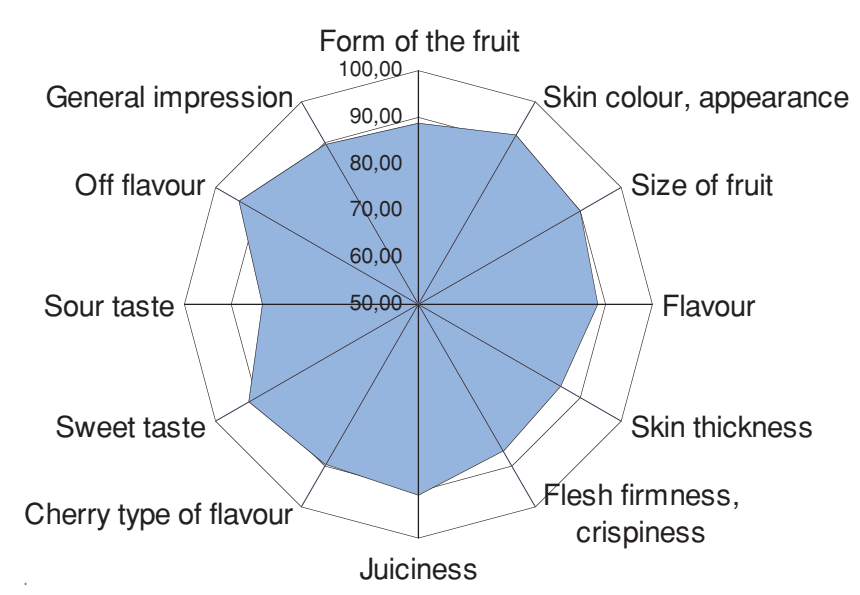

Figure 13. Profile diagram of the sensorial judgement of the variety Linda

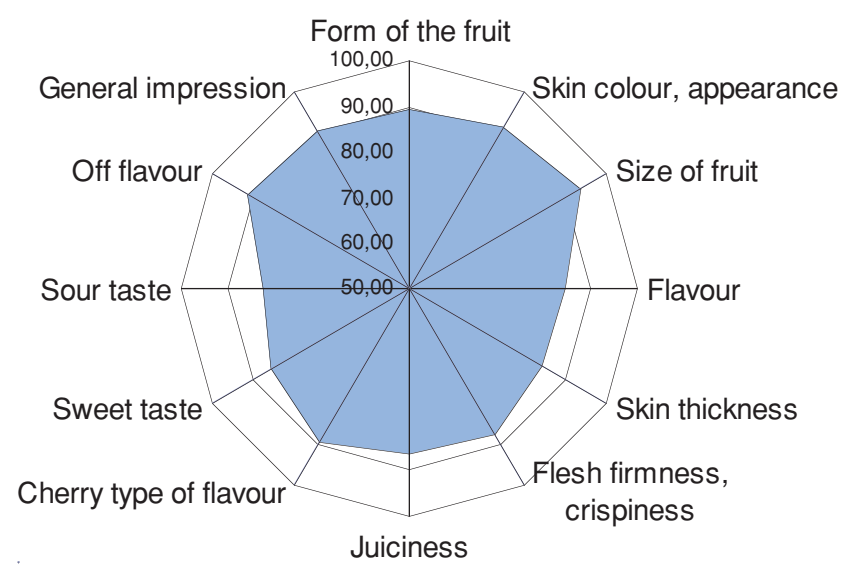

Figure 14. Profile diagram of the sensorial judgement of the variety Lapins

\section{Aknowledgement}

Research was sponsored by NFÜ TECH_08-A3/2-20080373 grant.

\section{References}

Apostol, J. (1999): Results of the sweet cherry breeding programme in Hungary. Acta Horticulture 484: 177-178.

Bernalte, M.J., Hernandez, M.T., Vidal-Aragon, M.C. \& Sabio, E. (1999): Physical, chemical, flavour and sensory characteristics of two sweet cherry varieties grown in 'Valle del Jerte' (Spain). Journal of Food Quality, 22: 403-416.

Christensen, J.V. (1995): Evaluation of fruit characteristics of 20 sweet cherry cultivars. Fruit Var. J. 49: 113-117.

Esti, M., Cinquanta, L., Sinesio, F., Moneta, E. \& Di Matteo, M. (2002): Physicochemical and sensory fruit chatecteristics of two sweet cherry cultivars after cool storage. Food Chem. 76: 399-405.

Girard, B. \& Kopp, T.G. (1998): Physicochemical characteristics of selected sweet cherry cultivars. Journal of Agricultural and Food Chemistry. 46: 471-476.

Guyer, D.E., Sinha, N.K., Chang, T.S. \& Cash, J.N. (1993): Physicochemical and sensory characteristics of selected Michigan sweet cherry (Prunus avium L.) cultivars. Journal of Food Quality. 16: 355-370.

Hampson, C.R., Quamme, H.A., Hall, J.W., MacDonald, R.A, King, M.C. \& Cliff, M.A. (2000): Sensory evaluation as a selection tool in apple breeding. Euphytica. 111: 79-90.

Kalyoncu, I.H., Ersoy, N. \& Yilmaz, M. (2009): Some phisicochemical properties and mineral contents of sweet cherry (Prunus avium L.) type grown in Konya. African Journal of Biotechnology. 8 (12): 2744-2749.

Kappel, F., Fisher-Fleming, R. \& Hogue, E.J. (1996): Fruit characteristics and sensory attributes of an ideal sweet cherry. HortScience. 31: 443-446.

Nobles, A.C. (1996): Taste-aroma interactions. Food Science \& Technology. 7: 439-444.

Nyéki, J. (2004): Means of pollination and factors affecting pollination. In: Floral biology of temperate zone fruit trees and small fruits (szerk: Nyéki J. - Soltész M.). Akadémia Kiadó, Budapest.

Revell, J. (2008): Sensory profile \& consumer acceptability of sweet cherries. Thesis of Masters of Research. Loghborough. 119.p.

Soltész M. (1997): Integrált gyümölcstermesztés. Mezőgazda Kiadó. Budapest.

Szabó, Z., Nyéki J. \& Soltész M. (1998): Csonthéjasok termesztésének helyzete és az intenzitás növelésének lehetőségei. „AGRO 21" Füzetek. 25: 36-46.

Takácsné Hájos, M., Nyéki, J. \& Szabó, Z. (2010): Organoleptic evaluation of pear varieties grown at different sites. International Journal of Horticultural Science. 26. (3): 33-39.

Turner, J., Colonna, A. \& Long, L.E. (2008): Consumer sensory evaluation of sweet cherry cultivars in Oregon, U.S.A. Acta Horticulture.795: 781-786.

Waterman, P. (2005): Cherry production trends in British Columbia. Acta Horticulturae. 667: 311-317. 